\title{
AUGER-TYPE GRANULAR FERTYLIZER DISTRIBUTOR: MATEMATHICAL MODEL AND DYNAMIC SIMULATION
}

\section{ANGEL P. GARCIA ${ }^{1}$, NELSON L. CAPPELLI ${ }^{2}$, CLAUDIO K. UMEZU ${ }^{3}$}

\begin{abstract}
The objective of this study was to model mathematically and to simulate the dynamic behavior of an auger-type fertilizer applicator (AFA) in order to use the variable-rate application (VRA) and reduce the coefficient of variation (CV) of the application, proposing an angular speed controller $(\dot{\theta})$ for the motor drive shaft. The input model was $\dot{\theta}$ and the response was the fertilizer mass flow, due to the construction, density of fertilizer, fill factor and the end position of the auger. The model was used to simulate a control system in open loop, with an electric drive for AFA using an armature voltage $\left(\mathrm{V}_{\mathrm{A}}\right)$ controller. By introducing a sinusoidal excitation signal in $\mathrm{V}_{\mathrm{A}}$ with amplitude and delay phase optimized and varying $\dot{\theta}$ during an operation cycle, it is obtained a reduction of $29.8 \%$ in the $\mathrm{CV}$ (constant $\mathrm{V}_{\mathrm{A}}$ ) to $11.4 \%$. The development of the mathematical model was a first step towards the introduction of electric drive systems and closed loop control for the implementation of AFA with low CV in VRA.
\end{abstract}

KEYWORDS: seeder fertilizer drill, modeling, precision agriculture.

\section{DOSADOR HELICOIDAL DE FERTILIZANTE GRANULAR: MODELO MATEMÁTICO E SIMULAÇÃO DA DINÂMICA}

RESUMO: O objetivo deste trabalho foi modelar matematicamente e simular o comportamento dinâmico de um dosador helicoidal de fertilizantes (DHF) a fim de utilizá-lo em aplicação a taxas variáveis (ATV)e reduzir o coeficiente de variação $(\mathrm{CV})$ da aplicação, propondo uma forma de atuação na velocidade angular de acionamento $(\dot{\theta})$ do seu eixo. A entrada do modelo foi $\dot{\theta}$ e a

resposta foi a vazão mássica de fertilizante em função de suas características construtivas, densidade do fertilizante, fator de enchimento e posição do fim do helicoide. O modelo foi usado na simulação de um sistema de controle em malha aberta, com o acionamento do DHF feito por meio de um motor elétrico com atuação na tensão de armadura $\left(V_{A}\right)$. Introduzindo-se um sinal de excitação senoidal em $V_{A}$ com amplitude e defasagem otimizada, consequentemente variando-se $\dot{\theta}$

durante um ciclo de operação, obteve-se redução no CV de 29,8 \% ( $V_{A}$ constante) para 11,4 \%. O desenvolvimento do modelo matemático foi um primeiro passo no sentido da introdução de acionamento elétrico e de sistemas de controle em malha fechada, visando à aplicação de DHF com baixos índices de CV em ATV.

PALAVRAS-CHAVE: semeadora-adubadora, modelagem matemática, agricultura de precisão.

\footnotetext{
${ }^{1}$ Eng. Agrícola, Bolsista do Programa Nacional de Pós Doutorado - PNPD - CAPES, Faculdade de Engenharia Agrícola, UNICAMP/Campinas - SP, Fone: (019) 3521.1746, garcia.angel@gmail.com.

${ }^{2}$ Eng. Agrícola, Prof. Livre Docente, Faculdade de Engenharia Agrícola, UNICAMP/Campinas - SP.

${ }^{3}$ Eng. Eletricista, Pesq. Doutor, Faculdade de Engenharia Agrícola, UNICAMP/Campinas - SP.

Recebido pelo Conselho Editorial em: 11-4-2011

Aprovado pelo Conselho Editorial em: 28-10-2011
} 


\section{INTRODUCTION}

The establishment of grain crops in Brazil extensively utilizes planter machines that apply fertilizer directly into the sowing furrow, usually by means of an auger-type fertilizer applicator (AFA). Application of fertilizers with these injectors is performed based on the average nutrient crop requirement, however when considering local needs, techniques must use technology with varying rate application (VRA). In modern agriculture, the use of VRA can only occur by means of machines that change the application rate according to the localized nutrient demand (OLIVEIRA et al., 2008).

CAPPELLI et al. (2000) studied the possibility to adapt commercial AFAs with VRA, and noticed that these devices show variation around the average application rate and that this feature, which is inherent to AFAs and resulted in an uneven application that can be expressed by its coefficient of variation (CV). YU et al. (2006), while developing a controller for a VRA injector, noticed that the $\mathrm{CV}$ is independent of the angular velocity of the dispenser's drive shaft and therefore does not depend on the average rate of fertilizer application. These studies show that since the $\mathrm{CV}$ of the application rate is inherent to the physical design of AFAs, uniformity of fertilizer distribution cannot be improved simply by changing the angular velocity of the dispenser's drive shaft or its project parameters, with no change in its original conception, nor by the introduction of a control system acting only on the average angular velocity of the dispenser's drive shaft.

An innovation in the AFA project was introduced by the company Agromac Ltd., in their model Fertisystem ${ }^{\circledR}$, through the use of a chamber with bulkhead to improve the oscillatory feature of the application. ULIANA et al. (2005) compared this system with conventional applicators and observed that the modified mechanism presented reduced the CV. GOETTEMS et al. (2010) found that the mean $\mathrm{CV}$ value for this dosing was $25.4 \%$. The variation of application was reduced, but still remained high.

The variation of application occurs within the time required to perform a complete revolution of the dispenser's shaft. To correct this variation, it is necessary to act on the control system during each operation cycle. The decrease in $\mathrm{CV}$ of the application rate can be achieved by varying the angular speed of the motor drive shaft of the auger during the cycle.

Several studies that aimed at developing application rate controllers were performed, but they ignored its oscillatory characteristic and acted only in the error of the angular speed. UMEZU \& CAPPELLI (2006) used a PID controller to change the proportional hydraulic flow valve, so that the angular speed of the hydraulic motor activates the dispenser's shaft. To set the application rate, a linear relationship between the angular speed of the shaft and the average mass flow rate was used. TOLA et al. (2008) developed a proportional type controller and the performance of the controller was carried out by means of electric motor acting on the lever arm of a variable gearbox and, consequently, the application rate. JAFARI et al. (2010) and YUAN et al. (2010) used a driver that worked in a DC electric motor to drive the seed and the fertilizer feeder, respectively. This type of engine has the ability to quickly change the shaft's angular speed, with the elements of the system being easy to install and perform when compared to hydraulic or mechanical actuators, such as those used by UMEZU \& CAPPELLI (2006) and TOLA et al. (2008), respectively. For the development of more advanced controllers, which act not only in controlling the angular speed of the feeder's axis, but also consider its characteristic oscillation, it is necessary to develop a mathematical model for simulations with different control strategies without the need of testing the real physical system (KIM et al., 2008, SAEYS et al., 2008).

The objective of this study was to obtain a mathematical model to describe the AFA behavior, simulate its performance and propose a way of acting in the angular speed of its drive shaft in order to reduce the $\mathrm{CV}$ of application. 


\section{MATERIAL AND METHODS}

\section{Considerations about the model}

The proposed model aims to simulate the instant mass flow of output in anauger-type fertilizer applicator according to its constructive characteristics, the angular position of the auger as a function of the fertilizer discharge point, and the angular speed of the applicator's drive shaft. The model entry is the angular speed of the drive shaft of the auger $(\dot{\theta}(t))$ in $\operatorname{rad~s}^{-1}$ and the output is the instant application rate $\left(\dot{m}_{i}(t)\right)$ in $\mathrm{g} \mathrm{s}^{-1}$. The parameters used were the useful surface of the auger (A) in $\mathrm{m}^{2}$, the auger pitch (p) in $\mathrm{m}$, the density of the fertilizer used $(\rho)$ in $\mathrm{kg} \mathrm{m}^{-3}$, and the applicator transport efficiency $(\eta)$, as illustrated in Figure 1.

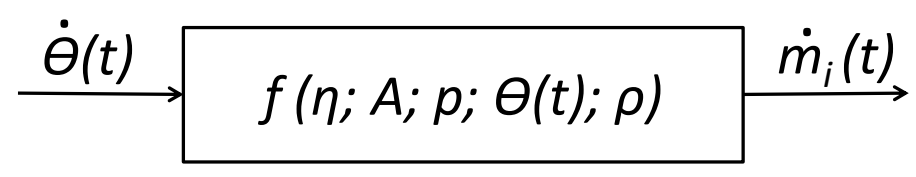

FIGURE 1. Block diagram of proposed model.

In the simulations, it was used four levels of the auger angular speed $2.72 \mathrm{rad} \mathrm{s}^{-1}\left(26 \mathrm{~min}^{-1}\right)$, $5.23 \mathrm{rad} \mathrm{s}^{-1}\left(50 \mathrm{~min}^{-1}\right), 7.33 \mathrm{rad} \mathrm{s}^{-1}\left(70 \mathrm{~min}^{-1}\right)$ and $14.66 \mathrm{rad} \mathrm{s}^{-1}\left(140 \mathrm{~min}^{-1}\right)$. These speeds were defined from the maximum and minimum angular speed applied to the shaft and their multiple dosing. CAMACHO-TAMAYO et al. (2009) presented a mathematical model of the average application rate provided by an auger-type applicator that correlates the angular speed and does not take time as a relevant factor in the expected application rate. This model showed a linear relationship between the application rate and the angular speed of the auger of the applicator. They also noticed that the transport efficiency $(\eta)$, which is a function of the design and type of fertilizer used, can be considered constant over time.

\section{Mathematical model}

In the mathematical model described by CAPPELLI et al. (2000), the mass flow rate of an auger-type fertilizer applicator is a function of angular speed of the shaft, the useful displacement surface, the thread pitch of the auger, and the fertilizer density, according to eq. (1).

$$
\dot{m}_{m}=\eta A p \dot{\theta} \rho
$$

where,

$\dot{m}_{m^{-}}$average mass flow of the applicator, $\mathrm{kg} \mathrm{s}^{-1} ;$ and

$\theta$-average angular speed of the drive shaft, $\operatorname{rad~s}^{-1}$.

The effective displacement surface is calculated according to eq. (2) and the efficiency of the transport mechanism is given by the ratio between the actual mass flow and theoretical mass flow (Eq. (3)).

$$
A=\pi\left(R^{2}-r^{2}\right)
$$

where,

$\mathrm{R}$ - outer radius of the auger, $\mathrm{m}$, and

$\mathrm{r}$ - inner radius of the auger, $\mathrm{m}$.

$$
\eta=\frac{\dot{m}_{r}}{A p \dot{\theta} \rho}
$$

where, 


$$
\dot{m}_{r^{-}} \text {average measured mass flow, } \mathrm{kg} \mathrm{s}^{-1} \text {. }
$$

This model is limited to the average application rate, i.e., it does not consider the variation of application rate over time. To be used in VRA systems, the model must take into consideration that there is variation in the rate of application during a rotation of the auger, as noted by CAPPELLI et al. (2000). This variation is a function of the transporter-charging factor $(f)$, related to its efficiency $(\eta)$ by eq. (4), and the position of the end of the auger in relation to the discharge point of the dispenser.

$$
f=(1-\eta)
$$

The oscillation of application rate during a turn of the auger is due to material drag, which concentrates near the auger, leaving an empty volume in the transporter. According to eq. (4), the filling factor is zero when the feeder is completely full $(\eta=100 \%)$. Only in this condition the application rate will be constant over time. It should be noted also that the lower the transport efficiency, the more inconsistent the fertilizer application will be. Typically, for auger-type applicators, the efficiency of transport does not depend on the angular speed of the auger axis, because, as noted by CAMACHO-TAMAYO et al. (2009), the application rate behaves linearly as a function of the angular speed of the drive shaft. In the same study, the authors noted that factors that affect the transport efficiency are associated with the physical characteristics of the fertilizer, such as density and embankment slope, as well as the design characteristics of the applicator mechanism.

The mathematical model considered that the range of mass flow rate provided by the applicator is the ratio between the minimum and maximum flow observed experimentally, eq. (5).

$$
K=\frac{\dot{m}_{\min }}{\dot{m}_{\max }}
$$

where,

$\dot{m}_{\min }, \dot{m}_{\max }-$ minimum and maximum observed flow rate, $\mathrm{kg} \mathrm{s}^{-1}$.

Considering that the flow variation occurs around a certain average flow (eq.(1)), associated with asinusoidal-type oscillatory component, whose amplitude is defined by the filling factor (eq.(4)), and normalizing the observed range of mass flow (eq.(5)), it can be equate the change in mass applied at each instant of time as a function of the angular speed and the position of the auger.

$$
\dot{m}_{i}(t)=K(A p \eta \rho) \dot{\theta}(t)\left\{\frac{1}{K}+[f \operatorname{sen}(\theta(t))]\right\}
$$

The eq.(6) is therefore the mathematical model to describe the instant mass flow rate of fertilizer depending on the angular speed of the drive shaft of the applicator mechanism.

\section{Validation and Simulation}

For simulation of the model, the computational mathematics program MATLAB was used. The experimental data were obtained using the system for measuring continuous mass flow proposed by CAPPELLI et al. (2000), as shown in FIGURE 2. In the system, a compound flow meter consisted of a load cell rated at $4.9 \mathrm{~N}$ coupled to a DC amplifier and a signal acquisition system. The load cell was mounted on a bulkhead with a slope of $45^{\circ}$, through which the fertilizer flowed. 


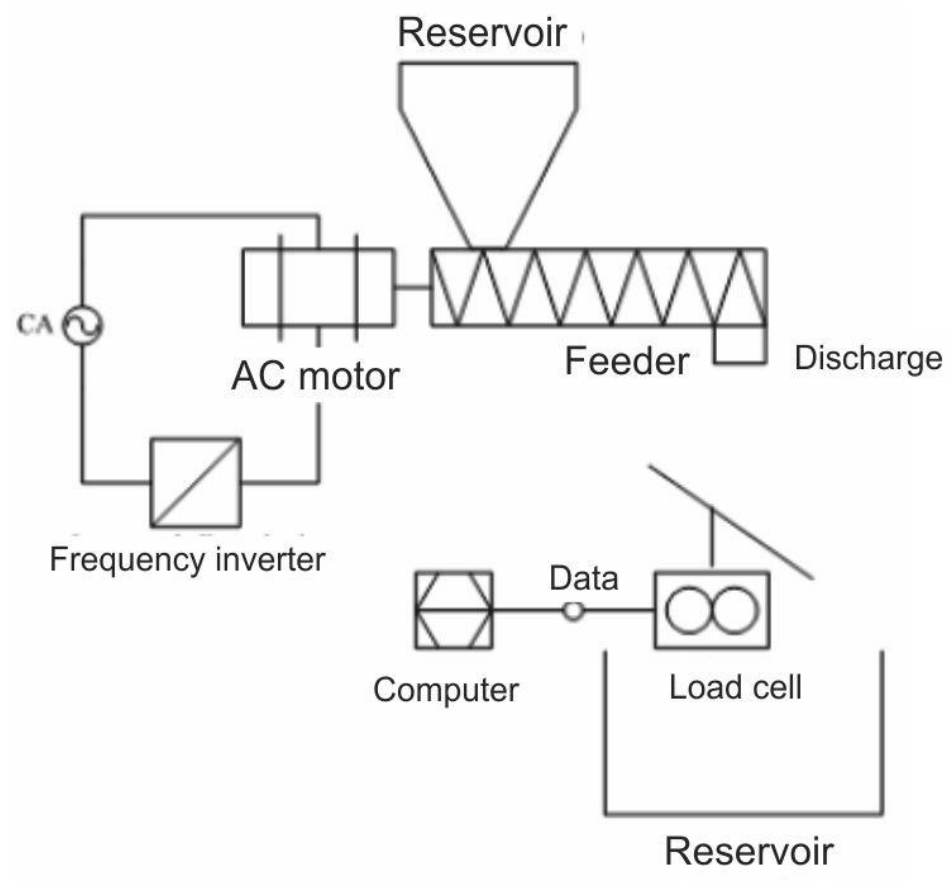

FIGURE 2. Schematic diagram of flow meter system.

Four trials were performed for different axis angular speeds of the fertilizer applicator: 2.72 $\operatorname{rad~s}^{-1}\left(26 \mathrm{~min}^{-1}\right), 5.23 \mathrm{rad} \mathrm{s}^{-1}\left(50 \mathrm{~min}^{-1}\right), 7.33 \mathrm{rad} \mathrm{s}^{-1}\left(70 \mathrm{~min}^{-1}\right)$ and $14.66 \mathrm{rad} \mathrm{s}^{-1}\left(140 \mathrm{~min}^{-1}\right)$. In each experiment, three repetitions were performed. Initially, it was selected the desired angular speed until the stabilization of the fertilizer flow, then the system was triggered to collect data for ten seconds, with an acquisition rate of $10 \mathrm{~Hz}$. The type of fertilizer used was a 4-20-20 NPK mixture, with bulk density of $1.13 \mathrm{~g} \mathrm{~mm}^{-3}$, embankment slope of $0.70 \mathrm{rad}\left(40^{\circ}\right)$, and weighted mean diameter of granules of $2.13 \mathrm{~mm}$. The fertilizer humidity was $2.78 \%$, measured before the tests started, since the temperature and humidity where the tests were performed were controlled thereby keeping the conditions constant during the tests.

\section{RESULTS AND DISCUSSION}

Data obtained from tests with the fertilizer applicator were filtered in post-processing in order to eliminate noise in the sampled signal. FIGURE 3 shows the results for each test, and their average mass flow rates during data acquisition.
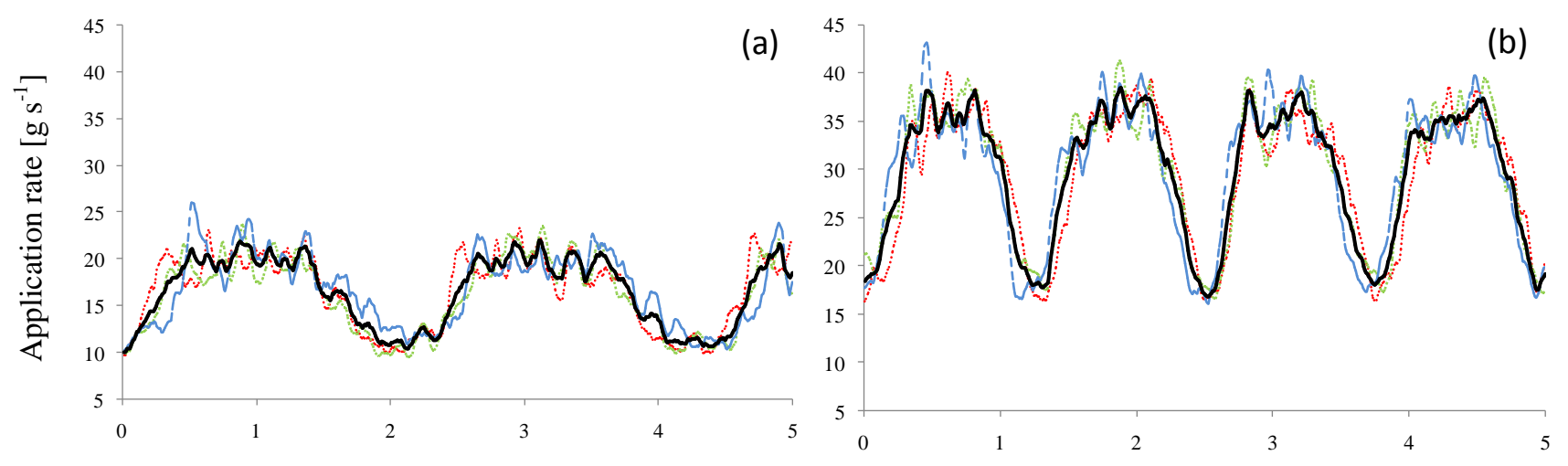


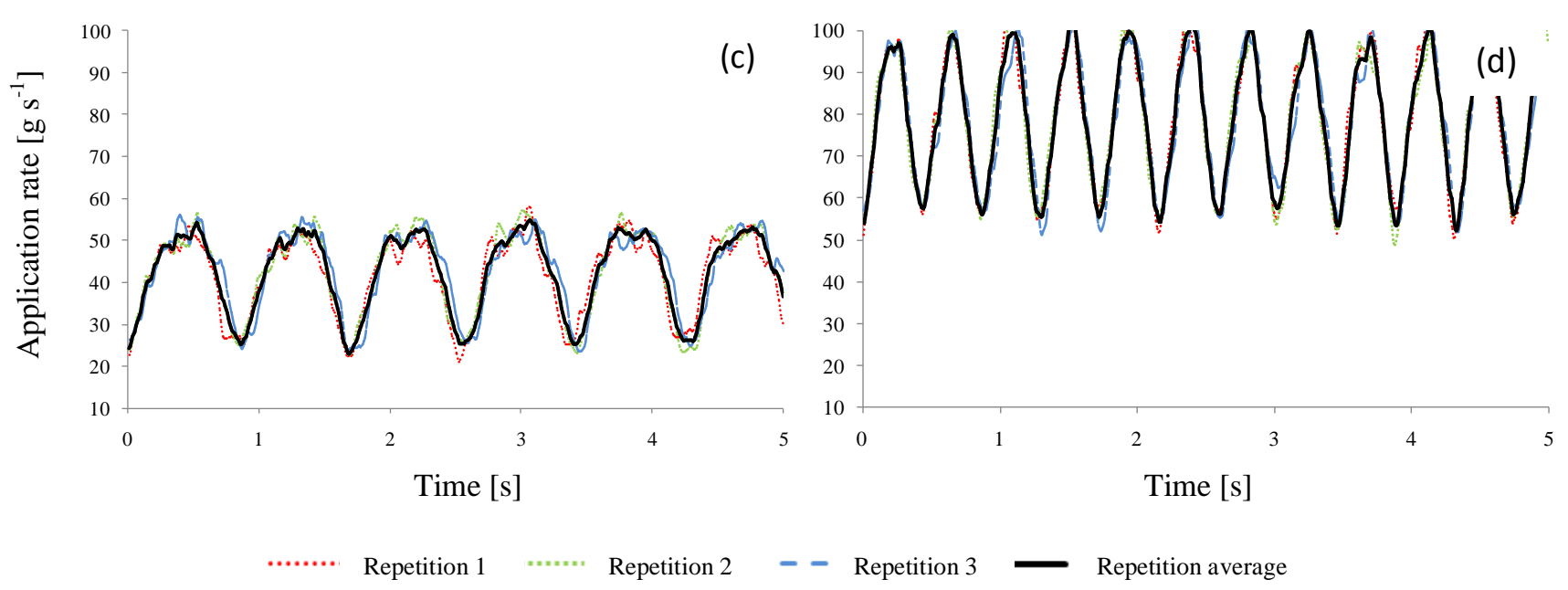

FIGURE 3. Fertilizer rate application versus time (a) $2,72 \mathrm{rad} \mathrm{s}^{-1}\left(26 \mathrm{~min}^{-1}\right)$; (b) $5,23 \mathrm{rad} \mathrm{s}^{-1}$ (50 $\left.\min ^{-1}\right)$; (c) 7,33 $\mathrm{rad} \mathrm{s}^{-1}\left(70 \mathrm{~min}^{-1}\right)$; and (d) $14,66 \mathrm{rad} \mathrm{s}^{-1}$.

The results obtained in the experiments are shown in Table 1. It is observed that the transport efficiency varied between $14.1 \%$ and $15.3 \%$ and was not statistically significant. The CV of the average application rate varied between $19.2 \%$ and $22.7 \%$, resembling the results obtained by GOETTEMS et al. (2010) with a similar auger-type applicator $(\mathrm{CV}=25.0 \%)$.

TABLE 1. Experimental average results according to angular velocity in radians per second, in brackets angular speed in rotations per minute.

\begin{tabular}{ccccccc}
\hline $\begin{array}{c}\text { Angular } \\
\text { speed } \\
\left(\mathrm{rads}^{-1}\right)\end{array}$ & $\begin{array}{c}\text { Efficiency } \\
(\%)\end{array}$ & $\begin{array}{c}\text { Maximum } \\
\text { flow } \\
\left(\mathrm{kgs}^{-1}\right)\end{array}$ & $\begin{array}{c}\text { Minimum } \\
\text { flow }\left(\mathrm{kgs}^{-1}\right)\end{array}$ & $\begin{array}{c}\text { Average } \\
\text { flow } \\
\left(\mathrm{kgs}^{-1}\right)\end{array}$ & $\begin{array}{c}\text { Coefficient } \\
\text { of variation } \\
(\%)\end{array}$ & $\begin{array}{c}\text { Confidence } \\
\text { interval } \\
\left(\mathrm{kgs}^{-1}\right)\end{array}$ \\
\hline $2.72(26)$ & $14.5 \mathrm{a}$ & 22.04 & 10.03 & 16.57 & 22.2 & \pm 2.46 \\
$5.73(50)$ & $15.3 \mathrm{a}$ & 38.45 & 16.85 & 29.75 & 22.7 & \pm 3.60 \\
$7.33(70)$ & $15.1 \mathrm{a}$ & 54.77 & 22.96 & 42.42 & 22.1 & \pm 4.39 \\
$\begin{array}{l}14.66 \\
(140)\end{array}$ & $14.1 \mathrm{a}$ & 103.62 & 52.14 & 79.06 & 19.2 & \pm 4.90 \\
\hline
\end{tabular}

Values with same letter are not significantly different for Tukey $95 \%$ confidence.

The independent variables of the model were: angular speed of the feeder, the angular position of the auger, and the auger geometric properties (useful surface and pitch.) The calculated variable was instant mass flow rate in $\mathrm{kg} \mathrm{s}^{-1}$, obtained from the numerical solution from eq.(6).

Finally, it was obtained the response curves of the model, calculated for the same experimental conditions. The data used in the simulation were: $17.0 \mathrm{~mm}$ inner radius, $23.0 \mathrm{~mm}$ outer radius, $753.9 \mathrm{~mm}^{2}$ surface area, and $45 \mathrm{~mm}$ pitch.

FIGURE 4 shows the result comparison obtained by means of the mathematical model with experimental results for different angular speeds of the drive shaft fertilizer applicator, as well as their correlation coefficients between the experimental and simulated curves. To obtain the confidence intervals of each test, the Student's distribution test was used for a confidence level of $95 \%$. 

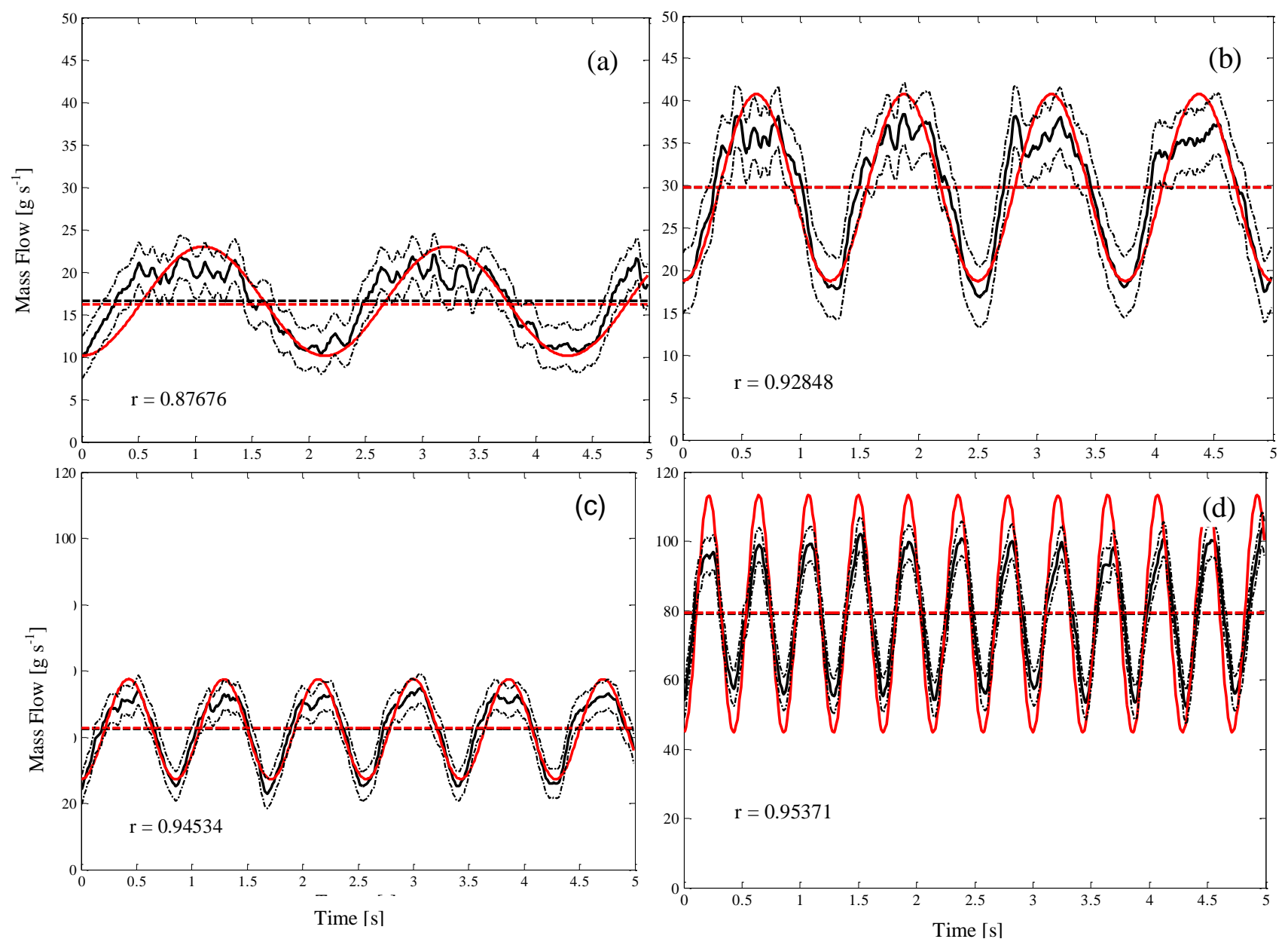

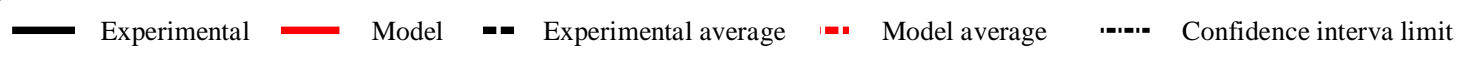

FIGURE 4. Comparison between the simulation model and experimental data, (a) angular velocity of $2.72 \mathrm{rad} \mathrm{s}^{-1}\left(26 \mathrm{~min}^{-1}\right)$, (b) angular velocity of $5.73 \mathrm{rad} \mathrm{s}^{-1}\left(50 \mathrm{~min}^{-1}\right)$, (c) angular velocity of $7.33 \mathrm{rad} \mathrm{s}^{-1}\left(70 \mathrm{~min}^{-1}\right)$ and (d) angular velocity of $14.66 \mathrm{rad} \mathrm{s}^{-1}\left(140 \mathrm{~min}^{-1}\right)$.

The mathematical model developed showed to be predictive and meaningful to describe the behavior of an instant mass flow of an auger-type applicator as a function of design parameters of the equipment and the operating conditions (angular speed and angular position of the auger's end at the discharge point). It was observed that the application rate could be simulated using mathematical models that take into account the charging factor defined by eq.(4). Eq.(6) was adequate for simulation of the fertilizer application rate in conventional auger-type applicator as well, with the dosing conceptually proposed. The proposed mathematical model remains to be tested in other auger-type applicators to analyze the influence of design parameters.

By simulating the rate of fertilizer applied as a function of time, for levels of transport efficiency between 15 and $95 \%$, it appears that as the transport efficiency increases, the inconsistency of application is reduced (FIGURE 5a). Notice, also, that the filling factor influences the quality of fertilizer application inversely to the efficiency. 

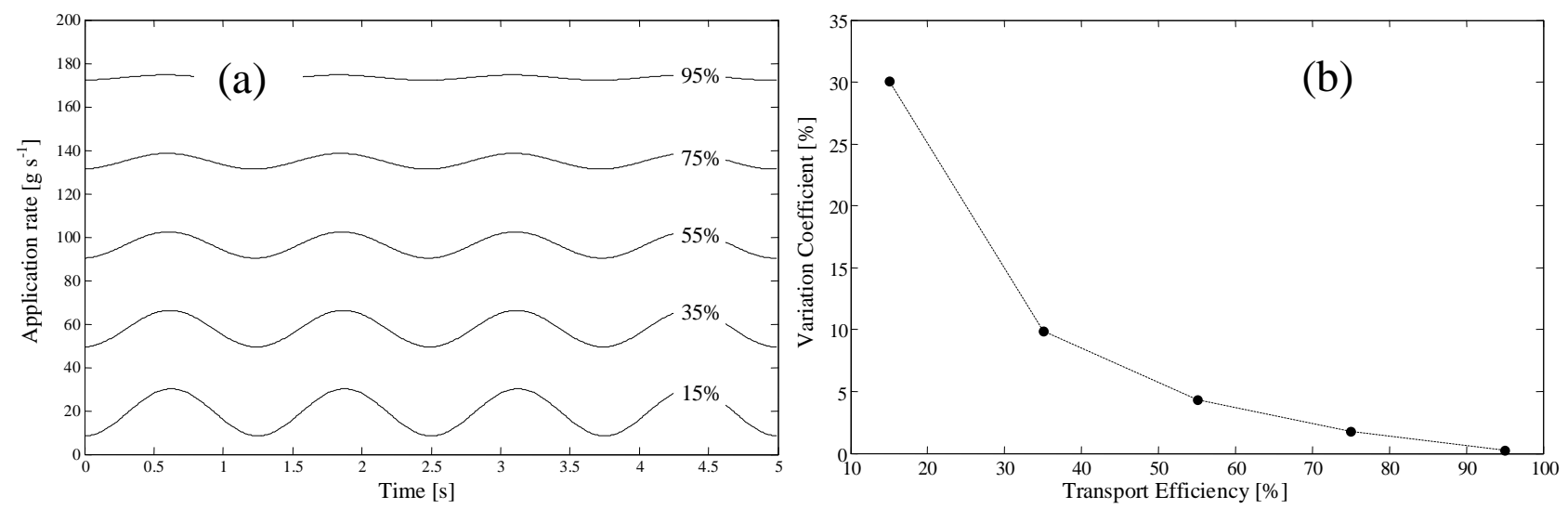

FIGURE 5. Simulation of the proposed model varying the efficiency of fertilizer applicator (a) variation of application rate versus time, (b) coefficient of variation versus transport.

The increase in efficiency reduces the coefficient of variation of application rate, as shown in FIGURE 5b. This is because the filling factor, according to eq. (6), is responsible for the oscillatory component of the system; therefore, this is the variable that directly affects the quality of fertilizer application regarding uniformity. Increasing the filling factor to improve the uniformity of application can only be accomplished by enhancing the transport efficiency, which in turn can only be obtained by changes in the original design of the applicator, for example, by redesigning the feeding gate or introducing an auger with variable pitch.

As noted from the results obtained by UMEZU \& CAPPELLI (2006) and CAMACHOTAMAYO et al. (2009), the mass flow rate as a function of average angular speed of the shaft of the applicator can be approximated by a linear curve. This corroborates that the angular speed of the drive shaft does not affect the transport efficiency of the applicator; otherwise it would be a noticeable non-linearity factor in the simulation results obtained. The CV of the application depends on the efficiency of the transport mechanism, i.e., for different drive angular speed the $\mathrm{CV}$ remains constant, as shown in the charts of FIGURE 4 and the results presented in TABLE 1. The same can be said for the other design factors that do not modify the transport efficiency.

Since there is no simple way to build an auger-type transport mechanism that operates close to its maximum efficiency and minimizes the negative effects caused by the oscillatory feature of the application created by the dispenser, a system can be used to control the angular speed of the shaft of the auger to make it possible to vary its angular speed during a drive cycle.

\section{Simulation of the motor-applicator system}

For the design of an open-loop control system for the application rate, a mathematical model was generated using MATLAB - Simulink. The model includes the fertilizer application mechanism, an electric motor and gear set, and the corresponding action signal. In the simulation, it was used the Dormand-Prince solving method (ode5), with fixed pitch between interactions of $0.001 \mathrm{~s}$. The method was used with reduced interval between iterations in order to eliminate possible errors caused by numerical resolutions.

In the simulation the applicator was driven by a DC electric motor operating in open loop. It was used a signal generator that has the function to simulate different excitation signals in the system. This signal passes through a $10-\mathrm{kHz}$ Pulse-Width Modulation (PWM) converter that provides a voltage signal, modulated in pulse width, to drive the electric motor, as normally used in a real physical system (FIGURE 6). 


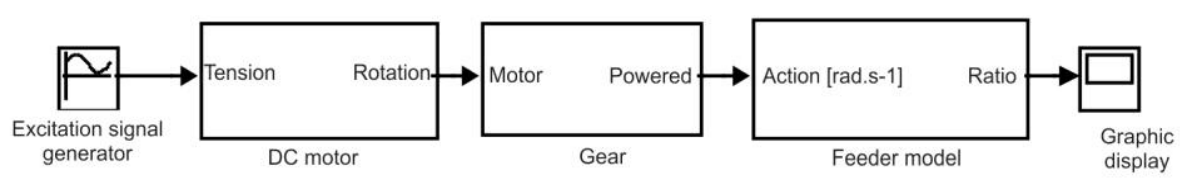

FIGURE 6.Block diagram of simulation of open-loop system in MATLAB-Simulink.

The transfer functions, eq.(7) and eq.(8), representing the electric motor used (direct current of permanent magnet) were described by FITZGERALD et al. (2006).

$$
\begin{aligned}
& G_{1}(s)=\frac{\Theta(s)}{V_{A}(s)}=\frac{K_{T}}{L J s^{2}+(J R+L B) s+\left(R B+K_{E} K_{T}\right)} \\
& G_{2}(s)=\frac{\Theta(s)}{F(s)}=-\frac{(L s+R)}{L J s^{2}+(J R+L B) s+\left(R B+K_{E} K_{T}\right)}
\end{aligned}
$$

where,

$G_{l}(s)$ and $G_{2}(s)$-transfer functions that represent the relationship between the angular speed of the shaft and the motor armature voltage in the first case, and dry friction in the second;

$\Theta(s)$-angular speed of the motor shaft, $\mathrm{rad} \mathrm{s}^{-1}$;

$V_{A}(s)$-applied voltage in the circuit of the motor armature, $\mathrm{V}$;

$F(s)$-representative of the dry friction constant, $\mathrm{N} \mathrm{m}$;

$R$ - armature resistance, $\Omega$;

$L$-inductance, $\mathrm{H}$;

$K_{E}$ and $K_{T}$ - emf constant and torque, $\mathrm{V} \mathrm{s} \mathrm{rad}^{-1}$ and $\mathrm{N} \mathrm{m} \mathrm{A}^{-1}$, respectively;

$J$-moment of inertia of the armature of the combined motor and charge, $\mathrm{kgm}^{2}$; and

$B$-viscous friction of the motor, $\mathrm{N} \mathrm{m} \mathrm{s} \mathrm{rad}{ }^{-1}$.

Because it was considered that the electric motor used has ideal behavior, the simulation output can be approximated by addition of the individual effects. Thus, eq. (10):

$$
G_{M}(s)=G_{1}(s) V_{A}(s)+G_{2}(s) F(s)
$$

The parameters used in the simulations were the electric motor and reducer, Motron brand, model MR210, with the main characteristics: rated power of $144 \mathrm{~W}$, input voltage of $24 \mathrm{~V}$, maximum angular speed of $6.28 \mathrm{rad} \mathrm{s}^{-1}, \mathrm{R}=0.36 \Omega, \mathrm{L}=28.4 \mathrm{mH}, \mathrm{K}_{\mathrm{E}}=1.67 \mathrm{~V} \mathrm{~s} \mathrm{rad}^{-1}, \mathrm{~K}_{\mathrm{T}}=1.67 \mathrm{~N}$ $\mathrm{m} \mathrm{A}^{-1}, \mathrm{~B}=0.032 \mathrm{~N} \mathrm{~m} \mathrm{~s} \mathrm{rad}^{-1}, F(s)=0.266 \mathrm{~N} \mathrm{~m}$ and $\mathrm{J}=0.027 \mathrm{~kg} \mathrm{~m}^{2}$.

The design characteristics considered for the applicator were: thread pitch of $45 \mathrm{~mm}$ and auger surface area of $754 \mathrm{~mm}^{2}$. The density of the fertilizer used was $1,130 \mathrm{~kg} \mathrm{~m}^{-3}$. FIGURE 7 shows the simulation results with the constant excitation of the motor armature voltage during the drive cycle and the corresponding response on the application rate.

Two steps were introduced in $6 \mathrm{~V}$ excitation signal system, the first after $1 \mathrm{~s}$ and the second after $4 \mathrm{~s}$ of the simulation started, corresponding to a desired change in application rate. A short delay in the response of the system occurs due to the dynamics of the electric motor. Since the transport efficiency is constant, the transport delay in the application is null and can be neglected. The delay due to the transport from the exit point of the applicator and the place of deposition of the fertilizer was also disregarded. Under these conditions the system response time was only $0.05 \mathrm{~s}$, showing that the available torque of the electric motor was sufficient to rapidly overcome the inertia of the application feeder plus transported fertilizer. This corroborates the results obtained by JAFARI et al. (2010) and YUAN et al. (2010) that indicate the possibility of using electric motors for working in these application systems. 


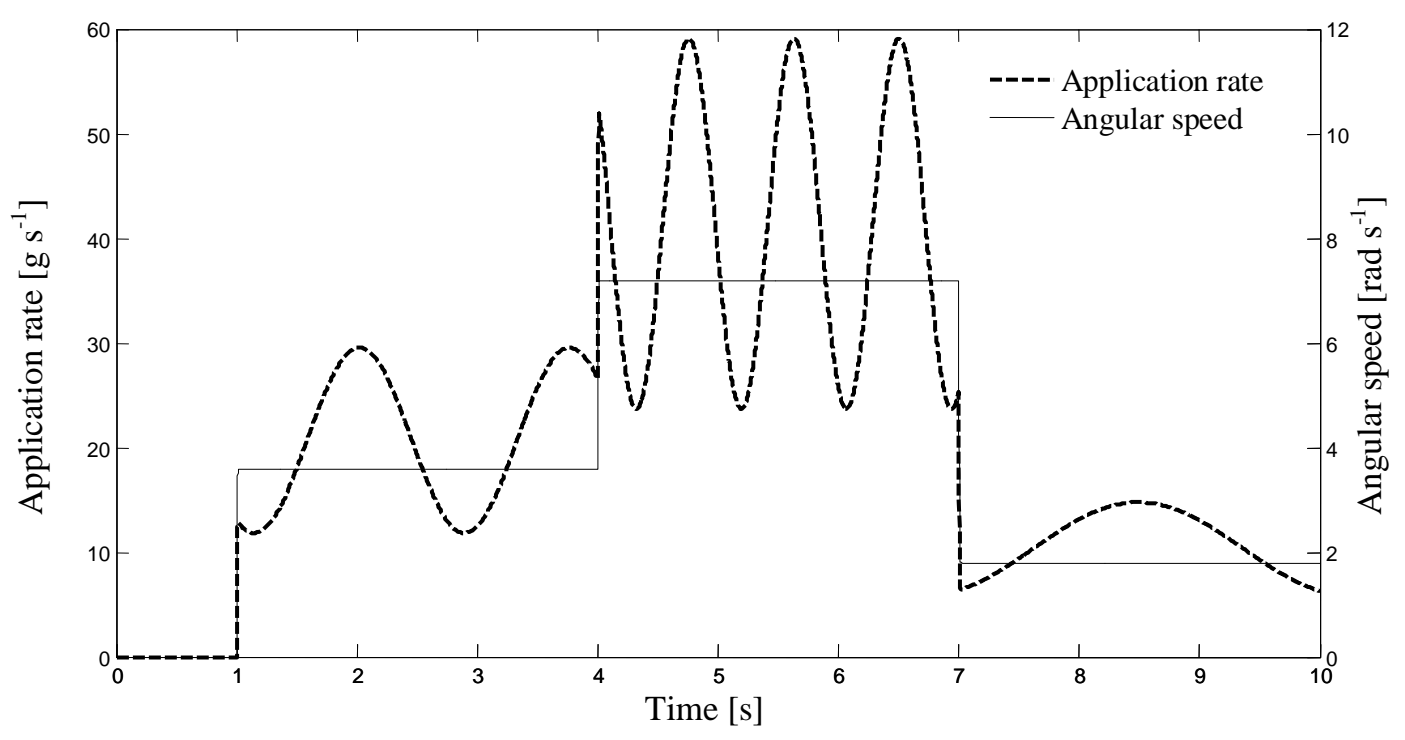

FIGURE 7. Simulation of the application rate versus time for the armature voltage constant in the motor drive operation cycle.

In order to study the possibility of reducing the CV by using a drive with variable angular speed during the operating cycle, it was used a sinusoidal generator with frequency equivalent to the average angular speed of the drive shaft of the applicator, with the signal amplitude ranging from 0 to $7 \mathrm{~V}$, which is equivalent to angular speeds between 0 and $4.2 \mathrm{rad} \mathrm{s}^{-1}\left(40.1 \mathrm{~min}^{-1}\right)$, reference value (bias) of $12 \mathrm{~V}$ and equivalent to $7.2 \mathrm{rad} \mathrm{s}^{-1}\left(68.8 \mathrm{~min}^{-1}\right)$ (midpoint of operation) and lag of $3.14 \mathrm{rad}$ $\left(180^{\circ}\right)$ to $2.50 \mathrm{rad}\left(143.2^{\circ}\right)$.

The graphs in FIGURE 8 show the behavior obtained for CV as a function of the amplitude of the signal delay. FIGURE 8a shows that in the initial condition, when the action was constant (zero amplitude of the sinusoidal signal), the oscillatory feature of the applicator is maintained and the CV was approximately 29\%. By increasing the amplitude of the excitation signal there is an attenuation of the $\mathrm{CV}$ to a minimum of $12.7 \%$, corresponding to a range of $4 \mathrm{~V}\left(2.4 \mathrm{rad} \mathrm{s}^{-1}\right)$. This is due to the compensation of the application rate by varying the angular speed in the operation cycle. As the amplitude of the action signal increases beyond this minimum point, the $\mathrm{CV}$ increases again because the compensation exceeded its maximum value.

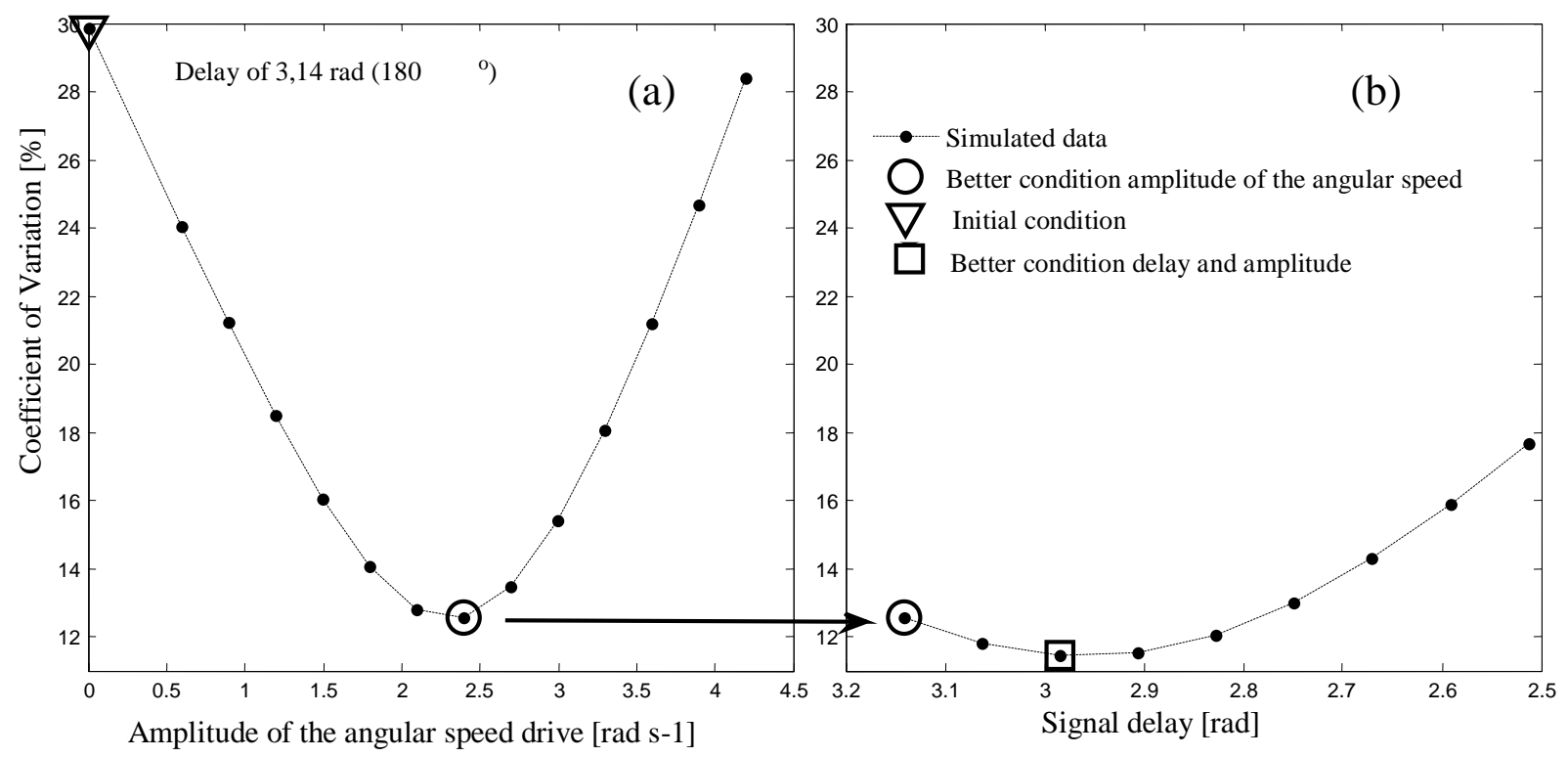


FIGURE 8. Simulation of the set electric motor auger type - feeder for a sinusoidal drive signal; (a) $\mathrm{CV}$ versus amplitude of the angular speed drive; (b) CV versus signal delay.

The CV can also be reduced due to the delay of the action signal. Figure $8 \mathrm{~b}$ shows that by reducing the gap from $\pi \mathrm{rad}\left(180^{\circ}\right)$ the $\mathrm{CV}$ decreases to a minimum of $11.5 \%$ at $2.98 \mathrm{rad}\left(170.7^{\circ}\right)$ of lag. This is to compensate the delay due to the dynamics of the electric motor, but without significantly affecting the movement synchronization between the sign and the change in application rate. As the gap becomes smaller, the dynamics of the motor becomes only partially compensated and the $\mathrm{CV}$ starts to increase due to the deterioration of that synchronism.

The application rate curve was simulated with ideal compensation conditions (range of $4 \mathrm{~V}$ and gap $2.98 \mathrm{rad}\left(170.7^{\circ}\right)$ ), as shown in FIGURE 9, and demonstrates a composition of two sinusoidal signals due to the association sine signal in series of action and intrinsic feature of the application with the auger-type feeder.

FIGURE 9 clearly shows the attenuation variation of the application rate obtained with the variable angular speed drive during an operating cycle, compared to that obtained with constant angular speed.

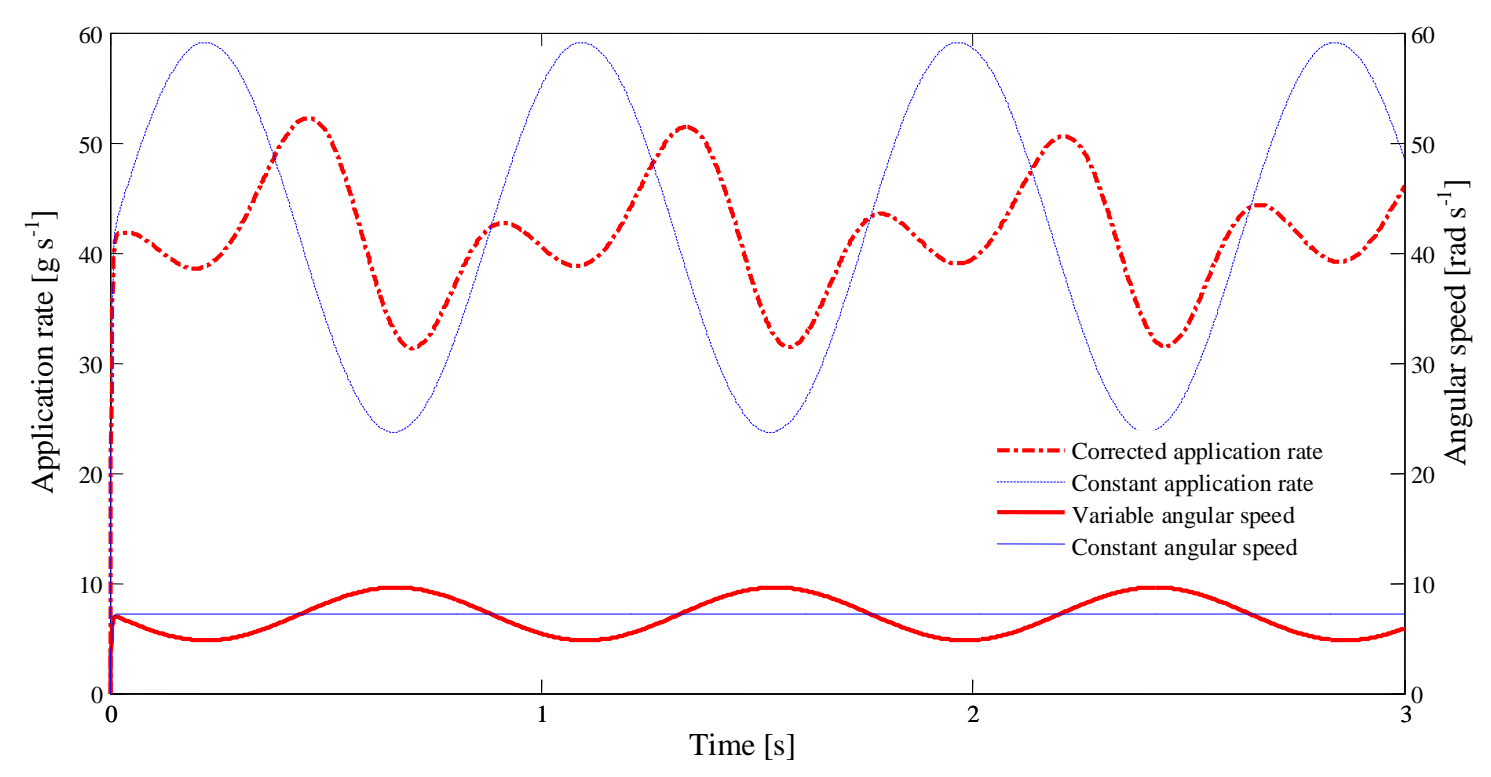

FIGURE 9. Rate application simulation versus time for constant and variable-cycle operation.

In simulations with reference values between 2 and $18 \mathrm{~V}$, equivalent to an average angular speed of the shaft applicator of $2.06 \mathrm{rad} \mathrm{s}^{-1}$ and $18.54 \mathrm{rad} \mathrm{s}^{-1}$, it appears that the amplitude of the optimal angular speed was approximately one third of this value. In turn, the optimal gap remained constant at $2.98 \mathrm{rad}$. This is the time constant of the electric motor set, which remains unchanged for several operating points.

It can be observed in the simulations that by changing the actions of angular speed of the auger applicator's drive shaft, it was possible to reduce the CV of the fertilizer application rate caused by the oscillatory component of the application mechanism. Thus, to reduce or even eliminate the fluctuation effect in the application of fertilizers with auger-type applicator, control systems that operate in the angular speed of the drive system can be used because of the error rate of application. 


\section{CONCLUSIONS}

The variation in the fertilizer application rate, performed with conventional auger-type applicators, is an intrinsic feature of these feeders and is a function of the transport efficiency of the applicator.

The proposed model proved to be adjusted to the values experimentally obtained. This model allows for simulations, to develop strategies for effective action in order to significantly reduce the $\mathrm{CV}$ of the fertilizer application rate.

The uniformity of application, expressed by the application rate CV can be reduced by acting on the angular speed of the auger's drive shaft during a cycle. By acting appropriately in the armature voltage of a DC electric motor and permanent magnet, the angular speed of the drive during an operating cycle of the fertilizer auger applicator can vary. The actuation signal (armature voltage) can be optimized by adjusting amplitude and lag. The dynamics of the electric motor has no substantial influence on the response application rate.

\section{REFERENCES}

CAMACHO-TAMAYO, J. H.;BARBOSA, A. M.; PÉREZ, N. M.; LEIVA, F. R.; RODRÍGUEZ, G. A.Operational characteristicsof four metering systems for agricultural fertilizers and amendments. Engenharia Agrícola, Jaboticabal, v.29, n.4, p.605-613, 2009.

CAPPELLI, N. L.; UMEZU, C. K.; MARTINS, M. M. Avaliação do desempenho de um dosador helicoidal para aplicação de fertilizantes sólidos. Engenharia Agrícola, Jaboticabal, v.20, n.2, p130$138,2000$.

FITZGERALD A. E.; KINGSLEY JR, CHARLES; UMANS, STEPHEN, D. Máquinas elétricas. 6 ed. Porto Alegre: Bookman, 2006.

GOETTEMS, J. M.; FEY, E; DOS REIS, G. Z; HOFFMAN, M.; MROZINSKI, C.Distribuição longitudinal de fertilizante em sistemas dosadores helicoidais modificados de semeadoras. In: CONGRESSO BRASILEIRO DE ENGENHARIA AGRÍCOLA, 39., 2010, Vitória. Anais... Vitória: Sbea, 2010. p. 1 - 4. CD-ROM.

JAFARI, M.; HEMMAT, A.; SADEGHI, M. Development and performance assessment of a DC electric variable-rate controller for use on grain drills. Computers and Electronics in Agriculture, Amsterdam,v. 73, n. 1, p. 56-65, 2010.

KIM, J. Y.; YANG, S. H.; RHEE, J.Y. Fertiliser application performance of a variableratepneumatic granular applicator for rice production. Biosystems Engineering, Amsterdam, v. 100, n. 4, p. 498-510, 2008.

OLIVEIRA, R. B. de; LIMA, J. S. de, XAVIER, A. C.; PASSOS, R. R.; SILVA, S.de A. SILVA, A. F. da. Comparação entre métodos de amostragem do solo para recomendação de calagem e adubação do cafeeiro conilon. EngenhariaAgrícola, Jaboticabal, v.28, n.1, p.176-186, 2008.

SAEYS, W.; DEBLANDER, J.; RAMON, H.; ANTHONIS, J. High-performance flow control for site-specific applicationof liquid manure. Biosystems Engineering, Amsterdam, v. 99, n. 1, p. 22-34, 2008.

TOLA, E; KATAOKA, T.; BURCE, M.; OKAMOTO, H.; HATA, S.Granular fertiliser application rate control system with integrated output volume measurement.Biosystems Engineering, Amsterdam, v. 101, n. 4, p. 411-416, 2008.

ULIANA, M. B.; FEY, E.; KUNZ, G. et al. Avaliação da uniformidade de distribuição longitudinal de adubo em semeadora adubadora utilizando rosca sem fim comum e modificada.In CONGRESSO BRASILEIRO DE ENGENHARIA AGRÍCOLA, 39., 2005, Canoas. Anais... Canoas: Sbea, 2005. p. 1 - 4. CD-ROM. 
UMEZU, C. K.; CAPPELLI, N. L. Desenvolvimento e avaliação de um controlador eletrônico para equipamentos de aplicação de insumos. Revista Brasileirade Engenharia Agrícola e Ambiental, Campina Grande, v.10, n.1, p.225-230, 2006.

YU, J. H.; KIM, Y. J.; RYU, K. H.Development of a Controller for Variable-RateApplication of Granular Fertilizer in paddy farming. In: ASABE ANNUAL INTERNATIONAL MEETING, 2006, Portland. Proceedings... Portland: Asabe, 2006. p. 1 - 12.

YUAN, J.; LIU, C. L.; LI, Y. M.; ZENG, Q.; ZHA, X. F. Gaussian processes based bivariate control parameters optimization ofvariablerategranular fertilizer applicator. Computers and Electronics in Agriculture, Amsterdam,v. 70, n. 1, 33-41, 2010. 